УДК 811.112.2(07)

DOI: $\underline{10.35619 / \text { iiu.v2i11.207 }}$

Терещенко Тетяна

кандидат філологічних наук, доцент, доцент кафедри практики німецької та французької мов Рівненського державного гуманітарного університету, м. Рівне, Україна ORCID: 0000-0003-3920-0547 e-mail: tetyana-tereschenko1@ukr.net

\title{
ЦИФРОВІ НОСІЇ ЯК ЗАСІБ ПЕРСОНАЛІЗОВАНОГО НАВЧАННЯ IНОЗЕМНОÏ МОВИ
}

Анотація. У статті оцінюється дієвість персоналізованого навчання, визначається доцільність упровадження цифрових засобів у традиційне заняття 3 метою підвищення ступеня персоналізації; обгрунтовується важливість використання цифрових носіїв для персоналізованого навчання іноземної мови. Доведено, що інформаційно-технологічний супровід особистісно-орієнтованого навчання вважається домінантною освітньою тенденцією, характерною рисою сучасної освітньої моделі. 3'ясовано, що цифрові носії використовуються не лише для того, щоб зробити зміст заняття цікавішим та заповнити його сучасною інформацією, а більшою мірою 3 метою персоналізації процесу навчання. Використання цифрових носіїв можна розглядати лише як складову частину комплексного процесу персоналізації. Успішне застосування цифрових носіїв для персоналізації передбачає поєднання фаз індивідуалізованого та кооперативного навчання у загальному навчальному процесі. У статті окреслено основні проблеми застосування інформаційнотехнологічного супроводу на заняттях 3 іноземної мови. Доведено, що керівництво викладача і систематичне залучення студента до планування траєкторії навчальної діяльності є передумовами до вичерпного і ефективного застосування цифрових носіїв.

Ключові слова: персоналізація, цифрові носії, компетентнісно орієнтоване навчання, інформаційно-технологічний супровід, траєкторія навчальної діяльності.

Постановка проблеми. Система вищої школи висуває високі вимоги до процесу навчання і особистості викладача, що безпосередньо вносить зміни і до методики викладання, і до змісту педагогічних практик. Однією з вимог сучасної вищої школи $\epsilon$ різноманітність прийомів і методів навчання. А оскільки у вищій школі тепер навчається покоління $Z$, представники якого виросли з інтернет і сучасними мобільними пристроями, то методика навчання не може бути осторонь потужних інформаційних процесів i обмежуватися традиційним навчанням. Оскільки процес засвоєння іноземної мови розглядається здебільшого як індивідуальний, то прогресивні педагоги підхопили ідею підкріплення використання паперового підручника застосуванням різноманітних інформаційних технологій. Інформаційно-технологічний супровід особистісноорієнтованого навчання вважається домінантною освітньою тенденцією, тому характерною рисою освітньої моделі $\epsilon$ створення спеціальних мобільних додатків для вивчення іноземних мов, які вносять елемент сучасності у традиційне заняття. Але саме викладач залишається головною особою, що в еру інформатизації здатен задати студентам правильний вектор навчання, використовуючи відповідні прийоми і методи, сформувати знання майбутнього 
Інноватика у вихованні. Випуск 11. Том 2. 2020.

вчителя іноземних мов.

Аналіз останніх досліджень 3 проблеми. Проблематика особливостей персоналізованого навчання на заняттях іноземних мов не є новою. Ціла низка вітчизняних і зарубіжних науковців (Т. І. Коваль, П. Г. Асоянц, Н. В. Майєр, А. О. Томіліна, Susan Patrick, Kathryn Kennedy, Scott Benson) присвятили свої дослідження різноманітним аспектам, вказуючи на залежність між формами використання цифрових мультимедійних технологій та способами оптимізації навчання (Коваль, Асоянц, Майєр, 2012). Варто згадати й дослідження М.Кадемія, що розглядає так зване «мобільне навчання»-M-Learning (Кадемія, 2011); Ю.Сафонової , яка аналізує мультимедійні мобільні додатки та Інтернет-сервіси як інструмент формування мовленнєвої компетентності учнів та конструктивної взаємодії на уроках німецької мови (Сафонова, 2018); В.Скачкової, яка описує використання мобільних технологій у навчанні (Скачкова, 2017). Хоча варто зауважити, що поняття персоналізованого навчання $є$ дуже багатошаровим (мета навчання, спосіб засвоєння матеріалу, темп навчання, цільова група) і застосування цифрових засобів забезпечує лише часткове вирішення питання. Представники персоналізованого навчання пропонують підбирати цифрові методи відповідно до індивідуальних потреб учнів. Останні можуть занурюватися у цифровий світ і, відповідно до власних потреб та інтересів, вибирати індивідуально цифрові навчальні програми.

Виклад основного матеріалу дослідження. Щоденна взаємодія викладачів і студентів завжди включала певну персоналізацію навчання, оскільки і викладачі, і студенти, як дві рівноправні сторони навчального процесу, завжди реагували на потреби та інтереси одне одного. Викладачі завжди персоналізують навчальний процес упродовж заняття, беручи до уваги можливості кожного студента до засвоєння навчального матеріалу. У цьому значенні персоналізація етаблюється як основа навчального процесу, що, в свою чергу, грунтується на заповненні прогалин між знаннями студента i вимогами викладача та виконанням навчального плану. Персоналізація навчання ставить питання доцільності існування такого поняття як середньостатистичний студент, більше того, дає можливість розглядати кожного як особистість із своїми потребами, інтересами та можливостями. Поняття персоналізованого навчання не є однозначним. Як показує аналіз наукової літератури, значення цього поняття залежне від часового пункту розгляду персоналізації і від відповідного контексту. У статті під поняття персоналізації ми розглядаємо «індивідуалізоване, компетентнісно орієнтоване навчання». Через складність поняття $\mathrm{i}$ відсутність загальновизнаного визначення, головна мета нашого дослідження - оцінити дієвість персоналізованого навчання, визначити доцільність впровадження цифрових засобів у традиційне заняття з метою підвищення ступеня персоналізації.

Основною метою персоналізованого навчання $\epsilon$ опанування спеціальними компетенціями. Поняття «персоналізоване навчання» часто вживають як синонім поняттю «компетентнісно орієнтоване навчання». За умов такого навчання студентів оцінюють відповідно до чітко поставлених цілей. Для успішного функціонування цього механізму, студент, в свою чергу, повинен добре розуміти мету навчання. Крім того, він повинен знати яким чином можна продемонструвати свої досягнення. Якщо не вдалося підтвердити досягнення конкретно поставленої мети, студент може отримати індивідуальну допомогу для заповнення прогалин у знаннях і вміннях (Томіліна, 2013). Поняття «персоналізоване навчання» менш вживане, порівняно з поняттями «диференціація» та «індивідуалізація». Воно вживається найчастіше з посиланням на англо-американський концепт personalized learning, який вперше з'явився у 1984 році, коли відомий психолінгвіст Benjamin Bloom заговорив про ефективність індивідуального навчання або навчання в малих групах під 
керівництвом тьютора (Patrick, Kennedy, Powell, 2013). Однак саме використання цифрових технологій і є тією відправною точкою, що розрізняє ці три поняття. Запровадження індивідуального навчання, навчання на онлайн-платформах, використання моделі змішаного навчання і розвиток новітніх інформаційних технологій дозволяє студентам мати більший доступ до потрібної інформації порівняно з попередніми поколіннями.

Упровадження технологій для підтримки персоналізованого навчання прослідковується, починаючи з 20-х років минулого століття. Тоді психолог Sidney Pressey винайшов першу так звану навчальну машину. Вона була спроєктована для полегшення праці вчителя: автоматично оцінювала результати тестів за принципом Multiple-Choice. При цьому учні отримували фідбек (feedback) i могли у такий спосіб відразу працювати над помилками, покращуючи свої успіхи. Цей пристрій удосконалив В. F. Skinner, дослідник у сфері поведінки. Він був виготовлений з дерева $з$ двома віконечками: в першому з'являлась смужка паперу із запитанням, на яке учні давали відповідь, записуючи в другому віконечку. Ці два винаходи вважаються попередниками персоналізованого навчання за допомогою цифрових засобів, оскільки вони, як досвідчені тьютори, дозволяли учням контролювати темп презентації навчального матеріалу. I саме це в подальшому лягло в основу процесу персоналізації навчання. Як вже зазначалося, персоналізація навчання через цифрові засоби передбачає надання учням свободи вибору про те Що, Коли і Як вони будуть вчити:

- персоналізація за цілями навчання: концепт персоналізації втягує учня у процес планування власного навчального процесу. При цьому сучасні цифрові технології роблять можливим процес навчання поза навчальною аудиторією, а викладач вже виступає в ролі тьютора. У навчальному процесі тьютор забезпечує індивідуальну підтримку кожному студенту. Важливою вимогою до тьютора є поєднання фахової і медійної грамотності. Крім того, поставлені цілі і запланований час на їх досягнення повинні бути грамотно сплановані i усвідомлюватися студентом, оскільки саме виконання певних завдань за допомогою цифрових носіїв $є$ передумовою для інтеграції досягнутих результатів у подальшому навчальному процесі;

- персоналізація за способом навчання: персоналізація навчання через цифрові носії $\epsilon$ взаємовигідною як для викладача, так i для студента. Зменшення витрат часу на адміністративну діяльність і оцінювання результатів дає можливість викладачу приділяти більше уваги соціальним і креативним аспектам навчання, оскільки студент повинен бути змотивованим до навчання, отримуючи постійну підтримку викладача або тьютора. Своєю чергою опанування мовою не обмежується лише аудиторними заняттями. Цифрові носії відкривають новий навчальний формат - змішане навчання (blended learning). Під змішаним навчанням іноземної мови ми розуміємо комбіновану систему професійно орієнтованого іншомовного навчання, яка передбачає активну комунікацію між викладачем і студентом за допомогою сучасних технологій та мультимедійних засобів (Габова, 2018). Використання електронних навчальних платформ робить комунікацію між викладачем і студентом швидшою і ефективнішою;

- персоналізація за змістом навчання: персоналізація навчання дає можливість розподіляти зміст навчання на зручні порції, що не переобтяжує студента і дозволяє засвоювати зміст без надмірних зусиль. Тут слід згадати програми intelligent tutoring system, під час застосування яких студент обирає свій темп навчання і отримує зворотну реакцію. Персоналізоване навчання можна застосовувати й для допомоги студентам покращувати написання власних текстів іноземною мовою (WriteToLearn), або мотивувати їх робити резюме на прочитані тексти (OpenEssayist). Ці програми дозволяють отримати feedback i таким чином, сприяють покращенню результатів навчання. Цифрові носії можуть 
використовуватися і в змішаному навчанні. Це може бути метод Flipped Classroom, де міняються місцями аудиторне заняття i домашні завдання. Студенти опрацьовують навчальний зміст вдома через онлайн-курс, а в аудиторії займаються проєктною роботою $\mathrm{i}$ практичним застосуванням пройденого матеріалу;

- персоналізація за темпом навчання: ще одним способом персоналізації навчання $\epsilon$ персональна ротація: студенти рухаються у власному темпі від однієї навчальної станції до іншої, причому алгоритм їхнього руху може задавати як викладач, так і програмне забезпечення. На відміну від інших видів станційної роботи, студент не повинен відпрацьовувати завдання на усіх станціях, а рухається за індивідуальним графіком. Як тільки студент опанує повною мірою заплановану тему, він може переходити до наступної. Швидкість таких переходів визначається як індивідуальний темп навчання. Навчальний темп може визначатися як для цілої групи, так і для окремих студентів. Періодично використовуючи інструменти оцінювання, студенти можуть переконатися, чи поставлені цілі були досягнуті перед тим, як рухатися далі. Програмне забезпечення постійно актуалізує індивідуальні профілі студентів після проходження кожної теми.

Упровадження персоналізованого навчання 3 цифровими засобами $є$ викликом для багатьох викладачів вищої школи. У багатьох навчальних закладах відсутня необхідна інфраструктура для застосування персоналізованого навчання в цілій групі. Як вирішення цієї проблеми можна запропонувати технологію BYOD (Bring Your Own Device) - «принеси свій власний пристрій». Цей термін вперше стали використовувати в 2009 році як новий підхід до організації робочого місця співробітника, який використовує власний мобільний пристрій (планшет, смартфон, ноутбук) для доступу до інформаційних ресурсів. Сенс BYOD в освіті полягає в тому, що викладачі і адміністрація навчальних закладів не забороняє, а дозволяє і всіляко мотивує студентів використовувати свої цифрові пристрої. Використання технології BYOD дозволяє розширити межі навчального процесу без часових і просторових обмежень. По-справжньому можливості мережі проявляються в таких навчальних ситуаціях, у яких студенти мають змогу працювати спільно над колективними проєктами. У цьому випадку приходять на допомогу хмарні сервіси, з чого випливає, що необхідною умовою BYOD підходу є формування у навчальному закладі хмари освітніх сервісів.

Основною проблемою вважаємо відсутність програм, які на основі аналізу індивідуальних даних могли б здійснювати аналіз сукупних досягнень окремих учнів із зворотнім зв'язком. Упровадження такого методу навчання має бути частиною цілої концепції навчального закладу: передбачає систему навчання викладачів і часу адаптації викладачів і студентів. Крім того, варто забезпечити захист особистих даних і навчити студентів керувати своїм навчальним процесом.

Висновки і перспективи подальших розвідок. Розглядаючи фаховий розвиток, ITінфраструктуру, лабільність викладачів та безпеку студентів, слід пам'ятати, що найважливішим є процес навчання. Захоплюючі нові технології можуть виявитися легкою спокусою. Однак, якщо ми справді хочемо підвищити потенціал застосування цифрових носіїв у персоналізованому навчанні, слід детально продумати цілі і застосовувати ці носії, враховуючи окреслені цілі. Необхідно пам'ятати про те, що персоналізація означає щонайменше відмову від соціальної взаємодії. Враховуючи те, що навчання - це не лише самостійне опрацювання навчального матеріалу, а й діяльність, що задовольняє соціальні потреби (студенти навчаються сприймати себе як частину навчальної спільноти) і охоплює навчання інших та загальне розуміння матеріалу, то використання цифрових носіїв можна розглядати лише як складову частину комплексного процесу персоналізації (підтримки студентів). Водночас приклади успішного застосування цифрових носіїв для персоналізації 
інтегрують у собі поєднання фаз індивідуалізованого навчання з кооперативним і загальним навчальним процесом. Персоналізоване навчання за допомогою цифрових носіїв слід розглядати як частину змішаного навчання. Варто зазначити, що цифрові засоби не можуть бути панацеєю до вирішення питання персоналізації навчання і ніколи не зможуть замінити викладача. Таке навчання $є$ ефективним тоді, коли проводиться під керівництвом викладача й інтегроване в звичайні аудиторні заняття. Тільки постійна підтримка викладача та систематичне залучення студента до планування траєкторії навчальної діяльності $\epsilon$ передумовами до вичерпного й ефективного застосування цифрових носіїв.

Подальші дослідження потребують вивчення інноваційних підходів до використання цифрових носіїв в процесі персоналізованого навчання іноземної мови.

\section{СПИСОК ВИКОРИСТАНИХ ДЖЕРЕЛ}

Коваль, Т. Асоянц, П. Майєр Н. (2012) Інформаційно-комунікаційні технології у навчанні іноземних мов для професійного спілкування. Київ : Вид. центр КНЛУ, 280 с.

Кадемія, М. (2011) Інформаційно-комунікаційні технології навчання: Словник-глосарій. Львів : СПОЛОМ, С. 136

Сафонова, Ю. (2018) Мультимедійні мобільні додатки та Інтернет-сервіси як інструмент формування мовленнєвої компетентності учнів та конструктивної взаємодії на уроках німецької мови. URL: https://itsey99.at.ua/publ/vystavka 2018/

Скачкова, В. (2017) Використання мобільних технологій у навчанні [онлайн]. URL: https://informatika.udpu.edu.ua/?page_id=3423 [Дата звернення 13.04.2020р.]

Томіліна, А. (2013) Використання електронної платформи Moodle при контролі й оцінюванні 3 англійської мови у вищому навчальному закладі. Теорія i практика використання системи управління навчанням Moodle. Київ, КНУБА. С. 67.

Patrick, S., Kennedy, K., Powell, A. (2013) Mean What You Say: Defining and Integrating Personalized, Blended and Competency Education. Oct., 2013. URL: https://www.capss.org/uploaded/2014_Redesign/Leadership_Development/Personalized_Learning_Ne wsletters/issue_6/iNACOL-Mean-What-You-Say-October-2013.pdf [Дата звернення 13.04.2020 p.]

Габова, М. (2018) Мастер-клас «Образовательный сайт: технология создания и использования». URL: http://wiki.kgpi.ru/mediawiki/index.php [Дата звернення 13.04.2020 p.]

\section{REFERENCES}

Koval, T. Asoiants, P. Maiier N. (2012) Informatsiino-komunikatsiini tekhnolohii u navchanni inozemnykh mov dlia profesiinoho spilkuvannia. [Information and Communication Technologies in the Teaching of Foreign Languages for Professional Communication] Kyiv: Vyd. tsentr KNLU, 280 s. (in Ukrainian).

Kademiia, M. (2011) Informatsiino-komunikatsiini tekhnolohii navchannia: Slovnyk-hlosarii. [Information and Communication Technologies of Training: Glossary]. Lviv: SPOLOM, s. 136 (in Ukrainian).

Safonova, Yu. (2018) Multymediini mobilni dodatky ta Internet-servisy yak instrument formuvannia movlennievoi kompetentnosti uchniv ta konstruktyvnoi vzaiemodii na urokakh nimetskoi movy [Multimedia Mobile Applications and Online Services as a Tool for Developing Students' Speaking Competence and Constructive Engagement in German Lessons]. URL: https://litsey99.at.ua/publ/vystavka 2018/ [Accessed 01/0422020]. (in Ukrainian).

Skachkova, V. (2017) Vykorystannia mobilnykh tekhnolohii u navchanni [Use of Mobile Technologies in Training]. URL: https://informatika.udpu.edu.ua/?page_id=3423 [Accessed 01/02/2020]. (in Ukrainian). 
Tomilina, A. (2013) Vykorystannia elektronnoi platformy Moodle pry kontroli y otsiniuvanni z anhliiskoi movy u vyshchomu navchalnomu zakladi. Teoriia i praktyka vykorystannia systemy upravlinnia navchanniam Moodle. [The Use of the Moodle Electronic Platform in the Control and Assessment of English in Higher Education. The Theory and Practice of Using the Moodle Learning Management System]. Kyiv, KNUBA, s. 67. (in Ukrainian)

Patrick, S., Kennedy, K., Powell, A. (2013). Mean What You Say: Defining and Integrating

Personalized, Blended and Competency Education. Oct., 2013. URL: https://www.capss.org/uploaded/2014_Redesign/Leadership_Development/Personalized_Learnin g_Newsletters/issue_6/iNACOL-Mean-What-You-Say-October-2013.pdf [Accessed 23/01/2020].

Gabova, M. (2018) Master-klas "Obrazovatelnyi sait: tekhnologiia sozdaniia i ispolzovaniia" [Master class "Educational site: technology of creation and use"]. URL: http://wiki.kgpi.ru/mediawiki/index.php [Access 13/01/2020]. (in Russian)

\title{
DIGITAL MEDIA AS A MEANS FOR THE PERSONALIZED TEACHING OF FOREIGN LANGUAGES
}

\author{
Tetiana Tereshchenko \\ $\mathrm{PhD}$ in Philology, Associate Professor, \\ Associate Professor at the Department \\ of Practice of German and French languages, \\ Rivne State University for the Humanities, \\ Rivne, Ukraine \\ ORCID: 0000-0003-3920-0547 \\ e-mail: tetyana-tereschenko1@ukr.net
}

\begin{abstract}
The article substantiates the importance of using the digital media for the personalized teaching of foreign languages. Future learning and work situations require from the students new kinds of knowledge. The digital media are being used not only to make the lesson content more interesting and to supplement it with up-to-date information, but also to a great extent with a purpose of the personalization of the process of teaching. The term personalized learning personalised learning is a potential approach to meeting future educational needs, it implies priority of the needs of individual students when developing curricula and learning materials. Students work at their own pace and the teachers can use a variety of online materials to prepare their lessons more efficiently and better customize them to the needs of the learners. The role of the teacher changes, but it is still of central importance in the learning process. Depending on the characteristics of the learning domains, some tasks and environments support individual work, while others will support a community of learners working on the same task. Mastering the characteristics of these tasks requires from the tutors a sound knowledge base. The teacher defines the learning goal and encourage learners to reach this goal by designing learning processes. Technologies are used to enable students the access to online materials and additional resources and to allow them, as active learners, to assess and monitor their progress. In introducing personalized learning it is important that digital media should be employed not just for the sake of following the latest technology trend, but for a certain purpose of the lesson. In the article it is proved that the teacher's guidance and systematic involvement of the student in planning of the learning path are prerequisites for the exhaustive and effective use of digital media.

Key words: personalization, digital media, competence based learning, information technology support, learning trajectory.
\end{abstract}

Стаття надійшла до редакиії 07.02.2020 р. 